\title{
Effects of dormancy-breaking treatments on seed germination of Pistacia species
}

\section{Pistacia türlerinin tohum çimlenmesi üzerine dinlenme azaltıcı uygulamaların etkileri}

\author{
Halil YASAR ${ }^{1}$, Izzet ACAR ${ }^{2^{*}}$ iD \\ ${ }^{1}$ Alata Bahçe Kültürleri Araştırma Enstitüsü, Erdemli, Mersin \\ ${ }^{2}$ Harran Üniversitesi, Ziraat Fakültesi, Bahçe Bitkileri Bölümü, Osmanbey Kampüsü, Haliliye, Şanlıurfa
}

\section{To cite this article:}

Yasar, H. \& Acar, I. (2019). Effects of dormancy breaking treatments on seed germination of Pistacia species. Harran Tarım ve Gıda Bilimleri Dergisi, 23(2): 206-210. DOI: 10.29050/harranziraat.445109

Address for Correspondence: Izzet ACAR

e-mail:

izzetacar@harran.edu.tr

Received Date:

18.07.2018

Accepted Date:

14.03.2019
(C) Copyright 2018 by Harran University Faculty of Agriculture. Available on-line at www.dergipark.gov.tr/harranziraat

\section{ABSTRACT}

This study was carried out to determine the effects of different dormancy-breaking treatments including stratification, sulfuric acid scarification, dehulling and gibberellic acid (GA3), on seed germination of different Pistacia species e.g. Pistacia vera cv. Kırmızı, Pistacia vera $\mathrm{cv}$. Siirt, $P$. khinjuk-A, P. khinjuk-B, P. atlantica, $P$. terebinthus and $P$. mutica using as rootstock for pistachio trees. Seed dormancy-breaking treatments were shelled (control), shelled $+\mathrm{GA}_{3}$, dehulled, dehulled $+\mathrm{GA}_{3}$, Sulfuric acid scarification and sulfuric acid scarification $+\mathrm{GA}_{3}$ applications in the experiment. The seeds of Pistacia species were stratified at $4{ }^{\circ} \mathrm{C}$ for 50 days after the dormancy-breaking treatments. Stratified seeds were sown in the seedling viols filled with peat in the greenhouse to determine the germination percentage. The highest germination rate was obtained from sulfuric acid scarification in $P$. khinjuk-A (96.7\%), and followed by dehulled application of $P$. vera $\mathrm{cv}$. Kırmızı and $P$. mutica species with $94.6 \%$ and $93.2 \%$, respectively. On the other hand, the lowest seed germination was observed for shelled $+\mathrm{GA}_{3}$ application of $P$. mutica with $6.7 \%$. When the seed germination rates of Pistacia sp. were examined, the highest germination occurred in $P$. vera cv. Kırmızı, and followed by $P$. khinjuk-B. The lowest germination rate was observed on $P$. atlantica.

Key Words: Pistacia sp., Stratification, Scarification, $\mathrm{GA}_{3}$, Seed germination

\section{Öz}

$\mathrm{Bu}$ çalışma, katlama, sülfürik asitle aşındırma, kavlatma ve $\mathrm{GA}_{3}$ uygulamalarını içeren farklı tohum dinlenmesini azaltıcı uygulamaların, antepfıstığına anaç olarak kullanılan Pistacia türlerinin (Pistacia vera-Kırmızı ve Siirt çeşitleri, P. khinjuk-A, P. khinjuk-B, P. atlantica, P. terebinthus ve $P$. mutica) tohum çimlenmesi üzerine etkilerini belirlemek amacıyla yürütülmüştür. Çalışmada kullanılan tohum dinlenmesini azaltıcı uygulamalar; kabuklu (kontrol), kabuklu $+\mathrm{GA}_{3}$, kavlak, kavlak $+\mathrm{GA}_{3}$, sülfürik asitle aşındırma ve sülfürik asitle aşındırma $+\mathrm{GA}_{3}{ }^{\prime}$ tür. Denemede kullanılan Pistacia türlerinin tohumları, tohum dinlenmesini azaltıcı uygulamalardan sonra $+4{ }^{\circ} \mathrm{C}$ 'de 50 gün katlamaya alınmıştır. Katlamadan çıkarılan tohumlar, serada içerisine torf doldurulmuş viyollere ekilmiştir.

En yüksek çimlenme oranı, $P$. khinjuk-A'da sülfürik asitle aşındırma uygulamasından elde edilmiş (\%96.7) ve bunu $P$. vera-Kırmızı ile $P$. mutica'da kavlatma uygulaması izlemiştir (\%94.6 ve \%93.2). En düşük tohum çimlenmesi ise $P$. mutica'nın kabuklu $+\mathrm{GA}_{3}$ uygulamasında (\%6.7) görülmüştür. Pistacia türlerinin tohum çimlenmesi tür bazında incelendiğinde, en yüksek çimlenme $P$. vera-Kırmızı çeşidinde görülmüş ve bunu $P$. khinjuk-B takip etmiştir. En düşük çimlenme oranı ise $P$. atlantica'da belirlenmiştir.

Anahtar Kelimeler: Pistacia türleri, Katlama, Asitle aşındırma, $\mathrm{GA}_{3}$, Tohum çimlenmesi 


\section{Introduction}

Pistacia genus is a member of the Anacardiaceae family and consists of at least eleven species (Zohary, 1952). Turkey has a large population of Pistacia species and several pistachio cultivars since Turkey is the genetic center of pistachio. Seven species, $P$. vera, $P$. terebinthus, $P$. khinjuk, $P$. atlantica, $P$. mutica, $P$. palaestina and $P$. lentiscus, are present and distributed in different regions of Turkey (Atlı et al., 2001). The main pistachio rootstock used in Turkey is $P$.vera, and it is followed by $P$. khinjuk, $P$. terebinthus and $P$. atlantica (Acar et al., 2017).

It was determined that $P$. atlantica and $P$. khinjuk rootstocks were better than $P$. vera rootstock in terms of tree vigour and crown formation of budded cultivars in dry conditions (Ulusaraç, 1992). Among the Pistacia species used as rootstocks for pistachio, it was determined that $P$. khinjuk is the best beneficiary of the soil nitrojen. Graft compatibility is well with pistachio cultivars, and no swelling or growth differences at the budding area (Atlı et al., 2001). There are two types of $P$. khinjuk in nature having large fruits $(A)$ and small fruits (B) $(A k, 1988)$.

Pistachio trees have significant potential for arid and semi-arid areas having suitable climatical conditions in the world. Pistachio cultivars are extremely difficult to propagate clonally on their own roots, and therefore rootstocks offer a simple method for propagate the pistachio cultivars (Acar et al., 2017).

Rootstocks can influence scion vigour, cropping, fruit quality, climatic adaptability, and susceptibility to pests and diseases. Until the mid$19^{\text {th }}$ Century, almost all of deciduous fruit tree rootstocks were raised from seed of fruits collected from indigenous wild populations. Usually, the seedling rootstocks and the fruiting clones grafted on them were of the same botanical genus and species (Webster, 1995).

There are many researches dealing with stratification, acid scarification and $\mathrm{GA}_{3}$ application on seed germination of different Pistacia species. Because the seeds of Pistacia species are surrounded by a hard sclerotic endocarp that makes it difficult to germinate, the germination rate in these species is low (Isfendiyaroglu and Ozeker, 2001). Various chemical solutions are used to stimulate seed germination. Gibberellic acid (GA) is one of the growth regulators which can be used to partially or fully replace the required period of cold moist stratification in a number of plant species (Baskin and Baskin, 1998). Scarification and cold stratification were found to improve the seed germination in Pistacia sp. (Ak et al., 1995). Seed scarification favours significantly the germination process, therefore it involved the fast inhibition of the tegument of seeds and the entry of water in the reserves that allows the fast exit of the root and the starting of the metabolic reactions of the embryo and the cotyledons (Ahoton et al., 2009; Chebouti-Meziou et al., 2014).

The objective of this study was to determine the effect of dormancy-breaking treatments on seed germination of Pistacia sp. using as rootstock for pistachio trees.

\section{Materials and Methods}

\section{Plant material}

This experiment was carried out in greenhouse of Harran University, Faculty of Agriculture, Department of Horticulture located in the Şanlıurfa province of Turkey.

Dried seeds of different Pistacia species e.g. Pistacia vera cv. Kırmızı, Pistacia vera cv. Siirt, $P$. khinjuk-A, $P$. khinjuk-B, $P$. atlantica, $P$. terebinthus and $P$. mutica were used in the experiment. The seeds were used to determine the seed germination in respect to dormancy-breaking treatments in the research.

\section{Treatments}

Six different dormancy-breaking treatments and cold stratification were applied to seeds. Treatments were a) shelled (control), b) shelled + $\mathrm{GA}_{3}$ application, c) dehulled, d) dehulled $+\mathrm{GA}_{3}$ application, e) Sulfuric acid scarification and $f$ ) Sulfuric acid scarification $+\mathrm{GA}_{3}$ applications. 
Treatments were;

Shelled (control): Seeds soaked for 24 hours in the water and then stratified at $4{ }^{\circ} \mathrm{C}$ for 50 days.

- Shelled $+\mathrm{GA}_{3}$ : Seeds soaked in the $500 \mathrm{ppm}$ $\mathrm{GA}_{3}$ for 24 hours and then stratified at $4{ }^{\circ} \mathrm{C}$ for 50 days.

- Dehulled: Seeds soaked for 24 hours in the water and then removed soft shells. Dehulled seeds were stratified at $4{ }^{\circ} \mathrm{C}$ for 50 days.

- Dehulled $+\mathrm{GA}_{3}$ : Seeds soaked for 24 hours in the water and then removed soft shells. Dehulled seeds soaked in the 500 ppm $\mathrm{GA}_{3}$ for 24 hours and then stratified at $4{ }^{\circ} \mathrm{C}$ for 50 days.

- Sulfuric acid scarification: Seeds were immersed in sulfuric acid during $30 \mathrm{~min}$ for Pistacia terebinthus, $60 \mathrm{~min}$ for $P$. atlantica and 90 min for $P$. khinjuk and $P$. mutica. Then seeds were washed and soaked for 24 hours in the water (Crane and Forde, 1974; Ak, 1988; Baninasab and Rahemi, 2001). Scarified seeds were stratified at $4{ }^{\circ} \mathrm{C}$ for 50 days. Since the endocarp is cracked in the $P$. vera cultivars, the sulfuric acid was damaging the embryo. For this reason, sulfuric acid scarification was not applied to seeds of $P$. vera cvs. Kırmızı and Siirt. Sulfuric acid scarification $+\mathrm{GA}_{3}$ : Seeds were immersed in sulfuric acid during 30, 60 and 90 mins in respect of species, and then washed and soaked for 24 hours in the water. Scarified seeds soaked in the $500 \mathrm{ppm} \mathrm{GA}$ for 24 hours and then stratified at $4{ }^{\circ} \mathrm{C}$ for 50 days (Crane and Forde, 1974; Ak, 1988; Baninasab and Rahemi, 2001). viols filled with peat in the greenhouse to determine the germination percentages. After 21 days from seed sowing, the plants emerging from germinated seeds were counted and seed germination rates (\%) were determined.

\section{Statistical analysis}

The experimental design was completely randomized design with 3 replications, and 25 seeds were used for each dormancy-breaking treatment in each replication of each Pistacia sp. genotypes. Data were analysed using Minitab 17 software (PA, USA, Minitab Inc.). Means were separated by Duncan's Multiple Range Test at $p \leq 0.05$.

\section{Results and Discussion}

The results obtained from the present study confirmed that dormancy-breaking treatments had an important effect on seed germination of Pistacia genotypes (Table 1). It was known that the exogenous application of various stimulants and inhibitors can affect the plant growth regulators levels and rates in the seeds and thus increase the germination rates (Baninasab and Rahemi, 2001; Mehanna et al., 1985). The highest germination rate was obtained from sulfuric acid scarification in $P$. khinjuk-A as $96.7 \%$, and followed by dehulled $+\mathrm{GA}_{3}$ application of $P$. terebinthus with $95.6 \%$ and dehulled application of $P$. vera $\mathrm{cv}$. Kırmızı with $94.4 \%$. The lowest seed germination was observed for shelled $+\mathrm{GA}_{3}$ application of $P$. mutica with $6.7 \%$.

Stratified seeds were sown in the seedling

Table 1. Effects of dormancy-breaking treatments on seed germination of Pistacia species.

Çizelge 1. Pistacia türlerinin tohum çimlenmesi üzerine dinlenme azaltıcı uygulamaların etkileri.

\begin{tabular}{lccccccc}
\hline $\begin{array}{l}\text { Treatments } \\
\text { Uygulamalar }\end{array}$ & $\begin{array}{c}\text { Pistacia } \\
\text { atlantica }\end{array}$ & $\begin{array}{c}\text { Pistacia } \\
\text { khinjuk-A }\end{array}$ & $\begin{array}{c}\text { Pistacia } \\
\text { khinjuk-B }\end{array}$ & $\begin{array}{c}\text { Pistacia } \\
\text { mutica }\end{array}$ & $\begin{array}{c}\text { Pistacia } \\
\text { terebinthus }\end{array}$ & $\begin{array}{c}\text { Pistacia vera- } \\
\text { Kırmızı }\end{array}$ & $\begin{array}{c}\text { Pistacia } \\
\text { vera-Siirt }\end{array}$ \\
\hline $\begin{array}{l}\text { Shelled } \\
\text { Kabuklu }\end{array}$ & $14.4 \mathrm{~d}$ & $33.3 \mathrm{e}$ & $53.3 \mathrm{~d}$ & $10.0 \mathrm{~d}$ & $20.0 \mathrm{c}$ & $55.4 \mathrm{c}$ & $50.8 \mathrm{c}$ \\
\hline $\begin{array}{l}\text { Shelled+GA } \\
\text { Kabuklu+GA }\end{array}$ & $15.6 \mathrm{~d}$ & $25.5 \mathrm{f}$ & $46.7 \mathrm{e}$ & $6.7 \mathrm{~d}$ & $17.4 \mathrm{c}$ & $81.5 \mathrm{~b}$ & $45.4 \mathrm{c}$ \\
\hline $\begin{array}{l}\text { Dehulled } \\
\text { Kavlak }\end{array}$ & $83.4 \mathrm{a}$ & $93.3 \mathrm{~b}$ & $83.3 \mathrm{~b}$ & $93.2 \mathrm{a}$ & $72.2 \mathrm{~b}$ & $94.6 \mathrm{a}$ & $75.4 \mathrm{a}$ \\
\hline $\begin{array}{l}\text { Dehulled+GA } \\
\text { Kavlak+GA }\end{array}$ & $55.6 \mathrm{bc}$ & $74.4 \mathrm{~d}$ & $74.4 \mathrm{c}$ & $68.9 \mathrm{c}$ & $95.6 \mathrm{a}$ & $89.0 \mathrm{a}$ & $60.8 \mathrm{~b}$ \\
\hline $\begin{array}{l}\text { Scarification } \\
\text { Asitle aşındırma }\end{array}$ & $53.3 \mathrm{c}$ & $96.7 \mathrm{a}$ & $90.0 \mathrm{a}$ & $83.3 \mathrm{~b}$ & $70.0 \mathrm{~b}$ & -- & -- \\
\hline $\begin{array}{l}\text { Scarification+GA } \\
\text { Asitle aşınd.+GA }\end{array}$ & $57.8 \mathrm{~b}$ & $86.7 \mathrm{c}$ & $85.6 \mathrm{~b}$ & $82.2 \mathrm{~b}$ & $74.0 \mathrm{~b}$ & -- & - \\
\hline
\end{tabular}

The letters following the numbers indicate different groups determined by Tukey test $(p \leq 0.05)$ 
When the seed germination rates of Pistacia sp. were examined, the highest germination occurred in $P$. vera cv. Kırmızı, and followed by $P$.
khinjuk-B. The lowest germination rate was observed on $P$. atlantica (Figure 1).

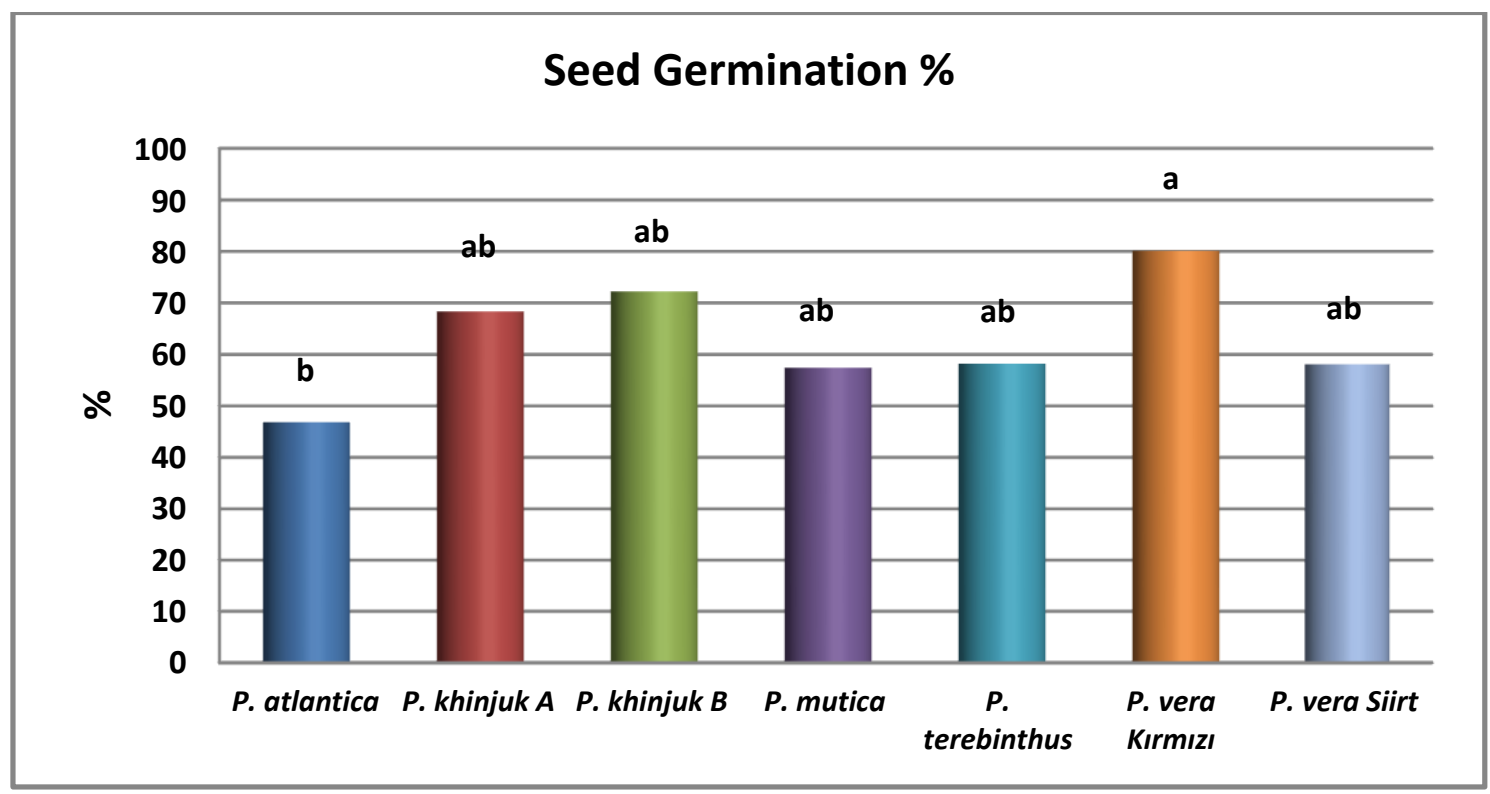

Figure 1. Seed germination rates of Pistacia species (\%). The letters over the columns indicate different groups determined by Tukey test $(\mathrm{p} \leq 0.05)$.

Şekil 1. Pistacia türlerinin tohum çimlenme oranları (\%). Sütunların üzerindeki harfler Tukey testi ile belirlenen farklı grupları göstermektedir ( $p \leq 0.05)$.

Kafkas and Kaşka (1997) were obtained the highest seed germination from the stratification and the lowest germination from the directly sown treatment in P. khinjuk types. It was stated that there were not significant differences between the scarified and scarified + prechilled seeds of $P$. lentiscus (Piotto, 1995). Besides, seeds soaking with 1000 ppm $\mathrm{GA}_{3}$ for 24 hours did not increase the germination percentages in $P$. atlantica and P. vera (Ak et al., 1995). On the other hand, Ak (1990), mentioned that the increases in stratification periods were found positively correlated with the germination percentages of $P$. vera and $P$. khinjuk seeds. Pipinis et al. (2014) reported that, in nonstratified seeds of Cotinus coggygria, acidscarified $+\mathrm{GA}_{3}$ treatment improved germination significantly, whereas in stratified seeds, no significant differences were observed in the germination percentages of $\mathrm{GA}_{3}$ treated and untreated seeds. Furthermore, the concentration of $\mathrm{GA}_{3}$ was not found to affect germination. AbuQaoud (2005) obtained the highest germination rate from $P$. palaestina acid scarified+cold stratified seeds as $60 \%$, on the other hand the germination rate of scarified seeds and scarified $+\mathrm{GA}_{3}$ applied seeds were $13.3 \%$ and $34 \%$ respectively in $P$. lentiscus.

As a conclusion, dormancy-breaking applications have been found to be effective on seed germination of Pistacia sp. It was determined that $\mathrm{GA}_{3}$ applications negatively affected seed germination as known to the contrary.

\section{References}

Abu-Qaoud, H. (2005). Effect of scarification, gibberellic acid and stratification on seed germination of three Pistacia species. An-Najah University Journal for Research 21: 1-11.

Acar, I., Yasar, H., Ercisli, S. (20179. Effects of dormancybreaking treatments on seed germination and seedling growth of Pistacia khinjuk Stocks using as rootstock for pistachio trees. Journal of Applied Botany and Food Quality 90:191-196.

Ahoton, L.E., Adjakpa, J.B., Akpo, E.L. (2009). Effet de prétraitements des semences sur la germination de Prosopis africana (Guill., Perrot. et Rich.) Taub., (Césalpiniacées). Tropicultura, 27(4): 233-238.

Ak, B.E. (1988). Investigations on seed germination of some Pistacia species. MSc thesis, Univ. of Cukurova, Adana, Turkey. 
Ak, B.E. (1990). Investigations on seed germination of some Pistacia species. Çukurova Univ. Journal of Science and Engineering Sci, 4(2): 125-139.

Ak, B.E., Özgüven, A.I., Nikpeyma, Y. (1995). The effect of $\mathrm{GA}_{3}$ applications on pistachio nut seed germination and seedling growth. I International Symposium on Pistachio, Acta Horticulturae 419: 115-120.

Atlı, H.S., Arpacı, S., Kaşka, N., Ayanoğlu, H. (2001). Wild Pistacia species in Turkey. In Toward a Comprehensive Documentation and Use of Pistacia Genetic Diversity in Central and West Asia, North Africa and Europe. Report of the IPGRI Workshop, 35-38.

Baninasab, B., Rahemi, M. (2001). The effects of scarification, cold stratification and gibberellic acid treatments on germination of Khokhong seeds, J. Plant Sci, 3: 121-125.

Baskin, C.C., Baskin, J.M. (1998). Seeds: Ecology, Biogeography, and Evolution of Dormancy and Germination. Academic Press, San Diego, 666 pp.

Chebouti-Meziou, N., Merabet, A., Chebouti, Y., Bissaad, F.Z., Behidj-Benyounes, N., Doumandji, S. (2014). Effect of cold and scarification on seeds germination of Pistacia atlantica L. for rapid multiplication. Pak. J. Bot., 46(2): 441-446.

Crane, J., Forde, H. (1974). Improved Pistacia seed germination. California Agriculture, 28(9): 8-9.

Isfendiyaroglu, M., Ozeker, E. (2001). The relations between phenolic compounds and seed dormancy in Pistacia spp. XI GREMPA Seminar on Pistachios and Almonds. Cahiers Options Méditerranéennes 56: 227-232.

Kafkas, S., Kaşka, N. (1997). The effects of scarification, stratification and $\mathrm{GA}_{3}$ treatments on the germination of seeds and seedling growth in selected $P$. khinjuk types. II International Symposium on Pistachios and Almonds, Acta Hort, . 470: 454-459.

Mehanna, H.T., Martin, G.C., Nishijima, C. (1985). Effects of temperature, chemical treatments and endogenous hormone content on peach seed germination and subsequent seedling growth. Scientia Horticulturae, 27(1-2): 63-73.

Piotto, B. (1995). Influence of scarification and prechilling on the germination of seeds of Pistacia lentiscus. Seed Sci. Technol., 23: 659-663.

Pipinis, E., Milios, E., Tomazos, N., Smiris, P. (2014). Breaking dormancy and germination of Cotinus coggygria Scop. seeds by means of Sulfuric acid scarification, cold stratification and gibberellic acid. Silva Balcanica, 15(1): 38-46.

Ulusaraç, A. (1992). Selection of rootstock for pistachio cultivars. Pistachio Research Inst. Pub. Gaziantep, Turkey.

Webster, A.D. (1995). Rootstock and interstock effects on deciduous fruit tree vigour, precocity, and yield productivity. New Zealand Journal of Crop and Horticultural Science, 23(4): 373-382.

Zohary, M. (1952). A monographical study of the genus Pistacia. Palestine J. Bot. Jerusalem Ser. 5:187. 